\title{
Philosophers and kings: response to William Bridges
}

Article

Accepted Version

Harloe, K. (2019) Philosophers and kings: response to William Bridges. History of Humanities, 4 (1). pp. 41-45. ISSN 23793163 doi: https://doi.org/10.1086/701983 Available at https://centaur.reading.ac.uk/80889/

It is advisable to refer to the publisher's version if you intend to cite from the work. See Guidance on citing.

To link to this article DOI: http://dx.doi.org/10.1086/701983

Publisher: The University of Chicago Press

All outputs in CentAUR are protected by Intellectual Property Rights law, including copyright law. Copyright and IPR is retained by the creators or other copyright holders. Terms and conditions for use of this material are defined in the End User Agreement.

\section{www.reading.ac.uk/centaur}

\section{CentAUR}

Central Archive at the University of Reading

Reading's research outputs online 
Author-final: last edited 30.09.18.

\section{Philosophers and Kings}

(Response to William H. Bridges, A Brief History of the Inhumanities, History of Humanities) Katherine Harloe, Associate Professor in Classics and Intellectual History, University of Reading

The Just City, ${ }^{1}$ the first in Jo Walton's trilogy of Thessaly novels, takes off from a scenario that should appeal to historians of humanities. In the Bronze Age, on the island of Kallisti (pre-eruption Santorini and a candidate location for the mythical Atlantis), the goddess Athene has gathered intellectuals from all places and periods in history who have at one time or another wished themselves citizens of Plato's ideal republic: her object its recreation on Earth. Just as in Plato's ideal city, the inhabitants of Athene's real-world experiment are organised in three classes: first, the 'Masters' - great philosophers of all ages, such as Crito, Cicero, Plotinus, Marsilio Ficino, and Pico della Mirandola; second, the 'Children' - 10,800 ten year-olds drawn from all periods and all social classes (Simmea, a principal 'Child' character, reveals that she was an Egyptian by birth who was bought in a slave market in Smyrna) and selected by the Masters for their intellectual promise and ability to speak Greek; finally the 'Workers' - not Plato's epithumetic desires, but robots brought (along with flush toilets, showers, and the literary and artistic treasures of all ages) from the future, which allow Athene and her philosopher-kings to pursue their utopian project without relying upon the 'uncomfortable' institution of slavery.

So far, so promising, though as early as Chapter 2, Simmeas' hint that the Masters may have stimulated slaving activity in their hunt for suitable Children may cause the reader to start asking questions. The cat is set among the pigeons, however, once Athene introduces into the mix... the historical Socrates, who soon proves just as irritating a gadfly to Kallisti's inhabitants as he had been to the nobility of Athens. And once Socrates begins to engage Workers in dialectic, they start to display the kind of sentience that renders the putatively 'ideal' status of the Just City increasingly questionable.

Walton's science-fictionalization of Plato's Republic and Laws contains many points of affinity with William H. Bridges' paper. Bridges' criticism of prior accounts of the humanities' value (including those that motivated the establishment of this journal) is significant partly because it exposes a crucial ambiguity in the way the question, 'Why are (or why aren't) the humanities important?' has been posed and answered. In the face of statements about the manifest value and innovative power of the humanities as a set of knowledge-making, problem-solving praxes, Bridges argues that any defence that focuses exclusively on the results the humanities deliver will fall short, as it will fail to demonstrate that participation in humanistic study, rather than consumption of the fruits of

\footnotetext{
${ }^{1}$ Jo Walton, The Just City (New York: Tor, 2015).
} 
Author-final: last edited 30.09.18.

humanistic labour, is good for everyone. If the products, but not the practice, of humanities are a universal good, the door remains open to a truly Platonic elitism, where it is sufficient for society if the philosophers philosophise and the welders weld.

Bridges identifies such elitism as a common thread in the deep history of the humanities, linking figures as diverse in identity and outlook as Marco Rubio and W.E.B. Du Bois. He turns away from the easy option of 'riposting [such] thinkers... from a philosophical field adjacent to the one from which their salvos originated', arguing instead that what he terms the 'existential' argument against the universal value of humanistic study - the idea that only some, but not all, derive benefit from its pursuit - must be engaged with and defeated on existential grounds. Rather than an account of what the humanities can deliver to all if a gifted minority is enabled to pursue them, Bridges hopes for an account of 'who' humans are: a specification of the human as, in his words, 'some irreducible singularity deserving of being and love (and humanistic education) simply because she exists' (p.4). What seems to be needed is a substantive account of human nature that shows why humanistic activity forms an essential part of the human good.

Bridges' 'brief history of the inhumanities' persuasively demonstrates that humanists are very far from having provided such an account. So widespread are the instances of exclusion, even in theories and educational systems as diverse as $4^{\text {th }}$-century BCE Greece, $6^{\text {th }}$-century CE Japan, and $16^{\text {th }}$-century Spain, that Bridges identifies a new metapattern in the history of humanities: 'the everpresent possibility of cannibalizing humanistic discoveries for inhumanistic pursuits'. From Aristotle's doctrine of natural slavery, to the deformation of the egalitarian impulses of Confucianism through their institutionalization in the Japanese ritsuryō system, to Hegel's racist assumptions about the intellectual and moral incompetence of Africans and Nietzsche's reflective claim that 'slavery belongs to the essence of a culture', Bridges exposes how students of humanities have, time and time again, not merely tolerated but argued for the subordinate status of another group, whose members resemble the truly human in various superficial respects but whose exclusion from that status is justified on the basis of their supposed lack of key capacities (reason, intellect, understanding) that would allow them to derive direct value from engagement in humanistic activity - and, one might add, political citizenship. If this account is correct, the history of the humanities does indeed reveal, in stark fashion, that inhumanity has been its inner and essential condition.

I do not set out here to assess the overall plausibility of Bridges' history - particularly on questions of Chinese and Japanese traditions of educational thought, in which I have no expertise. But given the depressing nature of the tradition he sketches, what prospect is there that some new, substantive account of human nature that is truly universal could hold out the hope of finally banishing the 
Author-final: last edited 30.09.18.

inhumanities? Another insight of Nietzsche's - that we humans are epistemically limited, perspectival creatures, who often have an interest in both maintaining and disavowing the inhuman substratum of our cherished ideals - gives little reason to hope that such an account will not end up, as in the case of Walton's Masters, abetting the human desire to both manufacture and disavow yet another exclusion. Little wonder that Bridges' discussion ends with a qualified defence of the 'infinite anomalies' and boundary questioning of post-structuralist thought.

Perhaps, however, the Nietzschean insight hints at what else could supplement the 'epistemological' argument for the humanities' value: an account of humanistic endeavour as a process of critical correction and enlarging of perspective. The humanities, it could be argued, train those critical and questioning skills that allow us to identify the exclusions and disavowals in past statements of actually-existing humanity; and precisely these are the cracks through which critique, and a move to something new, can take hold. ${ }^{2}$ Consider Aristotle's account of natural slavery at Politics 1254b, which forms one of Bridges' prime examples of inhumanity. Bridges is not quite right when he comments that, 'There is nothing particularly anti-Aristotelian in Aristotle's argument here'. For Aristotle's account is not sufficiently grounded in Aristotelian principles of critical observation, analogical thinking, and consideration of endoxa. His attempt to bolster his distinction between 'natural slaves' and 'natural masters (citizens)' founders on its evident lack of a firm ground in physical observation of nature - and Aristotle recognises this, although the recognition is uncomfortable for him:

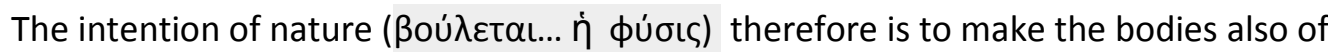
freemen and of slaves different-the latter strong for necessary service, the former erect and unserviceable for such occupations, but serviceable for a life of citizenship... though as a

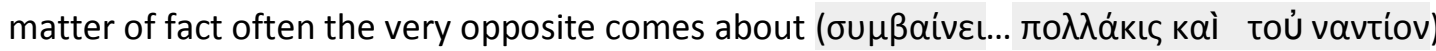
-slaves have the bodies of freemen and freemen the souls only; since this is certainly clear,

\footnotetext{
${ }^{2}$ So Wendy Brown on the position of (humanistic) political theory in the context of political science in "Neoliberalized Knowledge", an article Bridges draws upon: 'There are, to begin with, developed practices of epistemological and ontological reflexivity that would permit appreciation of the unstable, culturally variable and indeterminate nature of the constituent terms and practices of political life that the humanities could offer. Then there are the probing analyses of subterranean social and political powers which humanities fields have developed in recent decades, those powers organizing language, bodies, and spaces that in turn construct, array, and relate the collective and individual subjects, identities, and places studied by political science. Too, the humanities feature techniques of reading and interpreting meanings that may be conscious, unconscious, intentional, inadvertent or disavowed, a range for which the social sciences rarely train the eyes and ears. And, humanists have struggled with questions about the weight, shape, and force of history in the present; that is, with thinking about history not simply in terms of examples, accounts of development or context, but in terms of history's power to configure, condition, ghost or constrain our present orders, ordinances, predicaments and possibilities.' Wendy Brown, "Neoliberalized Knowledge," in History of the Present 1.1 (2011), 113-129, p. 116.
} 
Author-final: last edited 30.09.18.

that if freemen were born as distinguished in body as are the statues of the gods, everyone would say that those who were inferior deserved to be these men's slaves; and if this is true in the case of the body, there is far juster reason for this rule being laid down in the case of the soul, but beauty of soul is not so easy to see as beauty of body. ${ }^{3}$

Here Aristotle is reduced to positing a wished-for principle of nature that is not just occasionally, but 'often', breached rather than observed.

To turn to other of Bridges' examples, how great a gulf exists between Bartolomé de Las Casas' position in the Valladolid debates and his subsequent treatise, the Apologética historia de las Indias, and the egalitarian impulses Bridges identifies in the Confucian notion of ren humanity as cultivated sociability and community? In his reading of Las Casas' position, Bridges interprets the scholar as agreeing with Sepúlveda, that 'the humanity of the Native Americans is contingent upon their ability to be civilized'. This sounds as if Las Casas is holding out the future fact of the Americans' civilization as an empirical test of their humanity; yet in spite - or perhaps because of - his adherence to the 'biblical coherence principle', Las Casas's ethnography of the Native Americans could instead be read as an argument against any presumption of Native American 'inhumanity' that is contingent upon the conquistadors' inability to make sense of cultural and social customs very different from their own. In that case, far from endorsing a notion of humanity as an elite attribute awarded to those who conform to a set of substantively defined cultural expectations, Las Casas might be read as defending a standing presumption of the other's humanity based on acknowledgement of our own limited powers of imagination and interpretation.

If the force of such an argument were accepted, the resultant, hybrid account of the humanities' value would combine what Bridges terms an 'epistemological' argument about the power of the humanities to generate innovative solutions to real-world problems with an 'existential' argument about the epistemic limitations of human nature. If we cannot predict who is and is not capable of solving tomorrow's problems, for the good of humanity we should extend our view of humanistic capability, and the opportunity to engage in humanistic study, to encompass all. Who is included in that 'all' will be, and historically has been, a matter of intellectual, social and political contestation: the imperative to cast the net wide comes up against forces of irrationality, self-interest and disavowal, and history is one arena of this contest. ${ }^{4}$ Yet if one lesson of Bridges' brief history of the

\footnotetext{
${ }^{3}$ Aristotle, Politics 1254b28-39, tr. H. Rackham (Cambridge, MA: Harvard University Press, 1932).

${ }^{4}$ I believe a similar conception underlay both Hannah Arendt's conception of 'natality' and Edward Said's defence of Western (though not just Western) humanities in his late lectures on Humanism and Democratic Criticism. On the latter see my 'Questioning the Democratic, and Democratic Questioning', in Lorna Hardwick and Stephen Harrison, eds., Classics in the Modern World: A Democratic Turn? (Oxford: Oxford University Press, 2010), 3-13, pp. 9-13.
} 
Author-final: last edited 30.09.18.

inhumanities is the tendency of humanists to invent the inhuman as a constitutive other, another lesson of that history is the contestability and even defeasibility of the substantive boundaries that have, in the past, been drawn. A critical history of in/humanities might take as its purpose not only to unmask the inhumanity that has haunted every attempt to define the human, but also to excavate and develop those critical methods and insights that have enabled such exclusions to be contested and overcome.

\section{Works cited}

Aristotle. 1932. Politics. Translated by Henry Rackham. Cambridge, MA: Harvard University Press. Brown, Wendy. 2011. "Neoliberalized Knowledge." In History of the Present 1, no. 1: 113-129. Harloe, Katherine. 2010. "Questioning the Democratic, and Democratic Questioning.' In Classics in the Modern World: A Democratic Turn? Edited by Lorna Hardwick and Stephen Harrison. Oxford: Oxford University Press.

Said, Edward. 2004. Humanism and Democratic Criticism. New York: Columbia University Press. Walton, Jo. 2015. The Just City. New York: Tor. 